\title{
The Effect of eCRM Practices on eWOM on Banks' SNSs: The Mediating Role of Customer Satisfaction
}

\author{
Abdallah Q. Bataineh ${ }^{1}$ \\ ${ }^{1}$ Department of Marketing, Faculty of Economics and Administrative Sciences, Applied Science University, \\ Jordan \\ Correspondence: Abdallah Q. Bataineh, Department of Marketing, Faculty of Economics and Administrative \\ Sciences, Applied Science University, Amman, Jordan. E-mail: a_bataineh@asu.edu.jo
}

Received: February 13, 2015

Accepted: March 16, 2015

Online Published: April 25, 2015

doi:10.5539/ibr.v8n5p230

URL: http://dx.doi.org/10.5539/ibr.v8n5p230

\begin{abstract}
The main objective of this research is to examine the effect of electronic customer relationship management (eCRM) practices provided by banks operating in Jordan on electronic word of mouth (eWOM) on these banks social networking sites (SNSs) namely Facobook, Twitter and Instagram. Throughout a comprehensive reviewing of literatures in this growing area; the researcher built up a research model to describe the relationships between the research independent, dependent and mediating variables. Moreover, well structured questionnaire has been used to gather data from the research sample which consisted of 507 customers, who have had an e-transaction with their banks, and have active accounts on one or more of the previous SNSs. Accordingly, multiple regression test was used to analyze gathered data; the results showed that electronic direct mail, perceived rewards and interpersonal communication are respectively affect eWOM of banks SNSs. What is more, the mediating role of customer satisfaction was supported. Hence, conclusions, managerial implications and suggestions for upcoming researches are also provided.
\end{abstract}

Keywords: eCRM (interpersonal communication, electronic direct mail and perceived rewards), eWOM, SNSs, banking sector, Jordan

\section{Introduction}

The revolution of information technology has produced new and numerous relationships for organizations, and assisted them to take superior advantage of their existing relationships. By means of increasing worldwide penetration of the Internet tools; electronic customer relationship management (eCRM) has become more and more fashionable and strategic communication tool to build strong and long-term relationships with customers (Lam et al., 2013). Through the internet, all customers' touch-points with the organizations can be directly stored and analyzed, including the profitability of each customer account (Donaldson \& O'Toole, 2007). The core objective that eCRM system stands for is to serve customers properly and sustain the most precious customers. According to Wang and Head (2006) factors affect customer's intention to create well-built relationship with service providers through online channels are still blurred; and the majority of researches on the subject of online customers' behavior are focusing on customer acquisition rather than retention. For this reason, it costs organizations of gaining a new customer five to eight times of maintaining an existing one (Ross, 2005). Moreover, organizations with low customers' centric orientation well not only lose the current customers; they will also lose the prospects. According to Phelps (2001) "96\%" of dissatisfied customers never complain; but at least they will tell ten other customers about their unsolved problems. Otherwise, well-served customers can produce more income for the organizations and they will be excellent advertisers in the future (Reichheld \& Sasser, 1990). Therefore, internet can be used to amplify database marketing and create wide customers base for a life. Nevertheless, researches within the area of eCRM are to some extent limited and a number of scholars stress the call for more researches in this field (O'Reily \& Paper, 2009).

According to a report by PewGlobal (2013) the Internet usage rate in Jordan reached 47\%, where $84 \%$ out of total Internet users are using social networking sites SNSs. Therefore, banks can benefits from these SNSs whether as informative or persuasive tools through customers-generated content CGC. Furthermore, although online banking enables customers to interact with banks $24 / 7$ without time and place constraints; serving customers through online channels in Jordan still not fully formed. In view of that, customer experience with 
online banking especially through banks eCRM systems might have negative or positive perspectives between customers. In online context, customers are capable to share views through their banks' official websites, discussion forums and SNSs e.g. Facebook, YouTube, MySpace, Twitter etc., so they can strongly impact other customers attitudes toward these banks. According to Hennig-Thurau et al. (2004) electronic word of mouth eWOM still immature and needs more attention from marketing academics and practitioners. Since the concept of eWOM consider as a crucial element of the promotional mix (Yeh \& Choi 2011).

According to the website of Jordan chamber of industry (2015); service sector in Jordan forms $73 \%$ of gross domestic product GDP, and one of the most influential and key player in this sector is the banking industry. Factors like globalization and fast changing in Jordanian customers' lifestyle created fertile ground for banks operating in Jordan to extremely serve customers and make their life easier. Simultaneously, banks seems to have standardized tools to reach and serve their segments, which in a way or other shifted the power from banks to the customers; thus, customers started looking for the most powerful banks who can match and satisfy their needs through a package of distinguish offerings; which obligated banks to work hard to come up with customers demands and serve them effectively to retain them in the future. However, there are many reasons can drive Jordanians' customer to switch their current banks i.e.; lack of communication with customers whether through online or offline channels, service providing processes are running without accurate standards and disability to cope up with customers changing needs and wants.

Based on above discussion, the research originality and contribution to both eCRM and eWOM stem from: (1) a scholarly perspective, this is the first research effort in Jordan that attempts to build up a structure intended to realize the effect of eCRM practices on eWOM in the Jordanian banking industry, whereas the greater part of preceding researches conducted on conventional CRM practices and its effect on customers satisfaction, loyalty and sales etc., which initially also were concentrated intensively on technical issues related to the CRM system. On the other hand, from (2) a practical perspective, the research proposed model might offer powerful tool for marketing managers who are seeking novel marketing means from different sectors. Finally, the researcher wishes to set up a new research line in the field eCRM and eWOM in developing countries in general and in Jordan in particular. The importance of this research reflects the fact that eWOM on SNSs became an essential marketing tool for several businesses in Jordan. Accordingly, the main purpose of this research is to present banks marketers with experimental approaching concerning the effect of eCRM practices on eWOM on banks SNSs in Jordan.

\section{Research Background and Building Hypothesis}

\subsection{Electronic Word of Mouth eWOM on Banks Social Networking Sites SNSs}

With the emergence of social networking sites SNSs the quality and quantity of information customers can reach are tremendously massive, which make customers more reasonable in making different purchasing decisions of products and services basically derived from a real experience from other customers on these SNSs. Customers continuously attempt to discover and distribute information based on other customers' experiences with certain products/services (Petrescu \& Korgaonkar, 2011). A number of researchers make out the content sharing as a major distinction between traditional word of mouth WOM and eWOM communication (e.g. Henke, 2011; San José-Cabezudo \& Camarero-Izquierdo, 2012). The electronic word of mouth (eWOM) concept illustrates the interactive process occur via the online channels and strongly influence attitudes, believes, behaviors of individuals (Jobs \& Gilfoil, 2012). Products and services diversification and sophistication reinforce customers' needs to read and share more online opinions (Gil-Or, 2010). Customers look for the online opinions for many reasons i.e. decrease risk, secure lower prices and gain information etc., (Goldsmith \& Horowitz, 2006). In addition, the main driver that leads customers to share their reviews/comments appears when they are worry about others or they tend to augment their own self-worth (Amblee \& Bui, 2011). In the same context, Burton and Khammash (2010) confirmed that customers share their opinions online due curiosity and entertainment. In this research, eWOM concept will be reflected through pass-along behavior or (opinion sharing). In consequence, positive opinions provided by customers on SNSs about banks' practices through their electronic customer relationship management (eCRM) systems could be literary a precious indicator of customers' satisfaction and loyalty, or a nightmare of these banks with negative opinions.

\subsection{Electronic Customer Relationship Management eCRM}

According to Zineldin (2000) since the majority of organizations offer approximately similar core product/services, building strong and long relationships with customers could be the only way to differentiate certain organizations i.e. service firms. Traditional customer relationship management CRM has earned greater than ever awareness from service organizations in general and from banks in particular. In online context, 
electronic customer relationship management eCRM consider as a managerial tool that can be applied within different type of organizations. The concept of eCRM reflects the marketing activities, instruments and techniques carried out through the Internet, using technologies such as email, forums, the worldwide Web, chat rooms, social media and so on, with the aim of determining, building, and developing long-term relationships with customer (Lee-Kelley et al., 2003). Besides that, with the purpose to be the first customers' choice and keep growing in a purely competitive market like the banking industry in Jordan, customers' attraction is enormously insufficient. Banks in Jordan have to direct their capabilities to retain the most precious customers and grow up with them on long-term basis. Besides maintaining current customers, successful eCRM strategy allows organizations to reach new customers and collect priceless stakeholder data i.e. suppliers, distributers, agents etc., which is very necessary to organizations' development and competitiveness in the market (Harrigan et al., 2008). In this study, we investigate the influence of the affects of e-CRM on relationship quality, which in turn affects loyalty. With these insights, bankers and marketers can make more informed decisions on whether or not to invest in various types of e-CRM marketing tactics, which will hopefully increase their profitability and spawn continuous growth in their business in the highly competitive market, through relationship building with customers. Through using eCRM system, Jordanian banks can achieve many goals like (1) Focusing on the most valuable customers (2) build long-term relationships with customers with lowest amount of cost; (3) increase profitability from low-profit customers; (4) reduce customer churn or switching behavior (Jellasi and Enders, 2004). Based on that, this research tries to explore the relationship between eCRM practices provided by banks operating in Jordan such as (interpersonal communication, electronic direct mail and perceived rewards) and electronic word of mouth eWOM on banks social networking sites SNSs specifically (Facebook, Twitter and Instagram).

\subsubsection{Interpersonal Communication}

According to (Bataineh, 2015) the interpersonal communication concept was found to have high awareness in the field of social psychology; studies in this area have without fail established how individuals strongly impact each others to compare alternatives and make decisions for different matters. One of the most significant elements of eCRM system is communication, since the Internet has an interactivity characteristic which enables users to dynamically get involved in two-way of communications and to make a variety of transactions within the online framework (Lam, 2013). Communication with customers on regular basis considers focal point when the organization tends to improve the brand awareness, repeated communication help customers to store and easy recall information about certain brands (Percy, 2008). Banks' customer can search service-related information through the internet i.e. banks' official website or SNSs, which can reduce the perceived risks and assist customer to make more rational decision. Such behaviors possibly will be reflected in eWOM actions on banks SNSs, where exchange of information is for the most part affected by individual's perceptions of others on these SNSs (Shu-Chuan \& Yoojung, 2011). Thus, the following hypothesis can be proposed:

H1: There is an effect of interpersonal communication on eWOM on banks' SNSs.

\subsubsection{Electronic Direct Mail}

The interactivity feature of the internet make it possible for organizations to send personalized e-mail for their audience, tailored e-mail indicates organizations' readiness to get involved in one-to-one marketing. According to Yoon (2008) electronic direct mailing could be a newsletter used to keep customers updated about the organizations' activities. Organizations can be capable of recording the buying history and customers preferences, which can be used in the future to create customized products and services and estimate customers' behavior (Day \& Hubbard, 2003). In contrast to conventional promotional efforts, the cost advantage of electronic direct mailing enables organizations to personalize the relationship with customers in a cost-efficient manner (Lam, 2013). If banks in Jordan efficiently are capable to be customer -oriented, always trying to keep customers well informed about banks services and serving customers' precisely; then customers' loyalty almost will be increased, and then customers probably will share this advantage with others on banks SNSs. Thus, the following hypothesis can be proposed:

H2: There is an effect of electronic direct mail on eWOM on banks' SNSs.

\subsubsection{Perceived Rewards}

The majority of loyalty programs are intended to support increased usage of a organizations products or services, overall, the more a customer's purchase, the more rewards likely to receive (Liu, 2007). Rewarding customers can reinforcement purchasing behavior and make them keep doing business with the organizations (Sheth \& Parvatiyar, 1995). According to O'Brien and Jones (1995) rewards could create long relationships, especially if they in line with organizations resources. Expressively, giving free rewards to customers reflects the 
organizations appreciation of its customers (Lam, 2013). Consequently, if banks' customers receive gifts, cash, free of charge services or any type of incentives; they might tell other customers on banks SNSs about this treatment. Thus, the following hypothesis can be proposed:

H3: There is an effect of perceived rewards on eWOM on banks' SNSs.

\subsection{Customer Satisfaction}

Customer satisfaction has been significant topic for decades, especially within the area of customer behavior in the service sector e.g. financial services, health care services, insurance and education etc. Satisfaction has been viewed as the cornerstone in business relationships (Svensson's, 2009). Combining traditional CRM system with Internet tools assists organizations' to increase customer satisfaction (Krishnan \& Thorbjornsen et al., 1999). According to Davis-Sramek et al. (2009) they states in the context of a relationship marketing; customer satisfaction can be defined as customers' cognitive and affective assessment of services provided by an organization based on their personal experience. Hence, the organizational survival and progress hinges on retaining satisfied customers (Fecikova, 2004). Furthermore, Feinberg and Kadam (2002) investigated the relationship between eCRM components and customer satisfaction, they concluded that organizations should only match eCRM components on their websites with what satisfied customers view as important; as a result, organizations can save great financial or non-financial efforts. Based on this, if customers in Jordan were satisfied or dissatisfied with their banks; they will probably get engage in eWOM communications on banks SNSs. Thus, the following hypothesis can be proposed:

H4: The effect of eCRM practices on eWOM on banks' SNSs will be mediated by customer satisfaction.

\section{Research Model}

Throughout a comprehensive and well organized investigation of available previous researches and literature's in the area of electronic customer relationship management (eCRM), customer satisfaction and electronic word of mouth (eWOM); the following research model is developed by the researcher as shown in Figure 1, to demonstrate the relationships between the research variables.

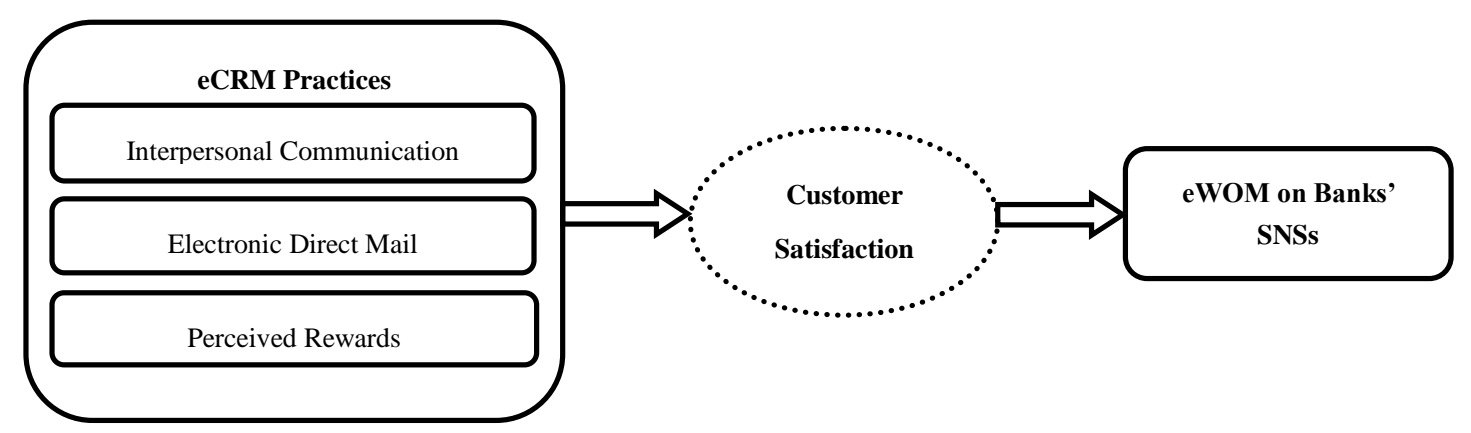

Figure 1. Proposed research model

\section{Research Methodology}

\subsection{Research Population and Sample}

According to the annual report issued by association of banks in Jordan (2014); the number of banks operating in Jordan is 26 banks; including 16 Jordanians banks and 10 foreign banks. Since the research scope focuses on banks' eCRM practices and eWOM through banks SNSs; the research population is consisted of all banks' e-customers in Jordan. After several contacts with marketing departments in all banks, it seems that they all carrying out various forms of eCRM practices primarily running within their official websites; nevertheless, the researcher unfortunately was incapable to obtain e-customers lists from banks operating in Jordan for competitive and privacy issues; what is more, all banks were refused to collaborate with the researcher instead of distributing questionnaires copies in the bank's branches, arguing it will confuse both employees and customers. Based on this, the research sample includes only: (1) customers who have had any e-transaction with their banks as part of the banks overall eCRM practices; and (2) customers who have an active accounts on these SNSs (Facebook, Twitter, and Instagram), and that was as filtering questions in the beginning of the research questionnaire (Appendix A). The rationales behind choosing these SNSs are; that they are commonly used by banks operating in Jordan; otherwise, they are easy to be recognized from most of targeted sample. 
A convenience sampling method has been applied in data gathering. This was identified by Diffley et al., (2011) since a convenience sample reflects easiness of sample selection and data gathering. The size of the research sample has been determined to be 640 in order to have a stable statistical analysis (Hair et al., 2010). Accordingly, to facilitate reaching this sample size; both traditional and electronic channels were employed to disseminate the 640 questionnaires. For traditional channel, the researcher relied on fieldwork and face-to-face communications with banks' customers in malls and coffee shops; whereas the electronic channels included emails and SNSs. Unfortunately, after more than two months of dissemination process; only 534 questionnaires have been returned, the response rate $83 \%$ was somehow high, while the number of questionnaires which were valid to be used for statistical analysis purposes was 507 out of the returned questionnaires; noting that 409 out of total questionnaires were obtained through the online channels, and the rest 125 through traditional one, although the response rate in online channels seems to be low compared with offline channels; this result appears reasonable since respondents can freely fill the questionnaire at home.

\subsection{Research Instrument and Data Gathering}

In order to achieve the purpose of this research, a structured questionnaire has been built based on appropriate literatures (Appendix A), and employed to collect data from the research respondents, whereas the research' measurements were obtained from prior researches as shown in Table 1. The research questionnaire consists of three parts as follow:

- Sample characteristics - which reflect respondents' general use of SNSs (Facebook, Twitter and Instagram).

- Sample demographics - including (gender, age, monthly income and educational level).

- eCRM practices as independent variables which includes (interpersonal communication, electronic direct mail and perceived rewards), and the mediating variable (customer satisfaction), and finally the dependent variable (eWOM on banks'SNSs). For each statement, Likert' five-point scale ranging from 5 (strongly agree) to 1 (strongly disagree) have been used.

Table 1. The research variables' measurements and their sources

\begin{tabular}{cc}
\hline Variable measurement & Reference \\
\hline eCRM Practices & \\
Interpersonal communication & (Lam, 2013) \\
Electronic direct mail & \\
Perceived rewards & (Hoehle et al., 2012) \\
Customer Satisfaction & (Shu-Chuan, 2011) \\
eWOM Sharing & \\
\hline
\end{tabular}

\subsection{Research Validity and Reliability}

The researcher applied both face validity and content validity before start distributing the research questionnaire; face validity was evaluated throughout the pilot efforts which were conducted with many scholars and practitioners within the research field, from distinguished Jordanian universities and reputable banks to check the appropriateness of the questionnaire to attain the purpose of the research. Alternatively, according to Churchil (2001) content validity reflects the methodology used to build up the research questionnaire which already developed based on previous researches as shown in table 1. For research reliability, the questionnaire was assessed through investigating the coefficient of cronbach's alpha which range from 0 to 1 (Sekaran \& Bougie, 2013). As shown in Table 2, all of the variables included in this research were greater than $60 \%$ which is the cutoff point used in this research, which ranged from (0.753 to 0.870). Consequently, the research questionnaire and variables have internal reliability coefficient. 
Table 2. Reliability coefficients for the research variables - Cronbach's alpha

\begin{tabular}{ccc}
\hline Variables & Number of Items & Cronbach's Alpha \\
\hline Interpersonal communication & 3 & 0.854 \\
Electronic direct mail & 3 & 0.870 \\
Perceived rewards & 3 & 0.822 \\
Customer satisfaction & 4 & 0.769 \\
eWOM on Banks' SNSs & 3 & 0.753 \\
\hline
\end{tabular}

\subsection{Variance Inflation Factor (VIF) Test}

As shown in Table 3 the VIF values are ranged between 2.382 and 2.799, and the values of tolerance are ranged between 0.357 and 0.420 . Thus, all the VIF and tolerance values calculated in the regression models point out that the multicollinearity problem is not of an enormous concern in this research. This was identified by (Hair et al., 2010).

Table 3. VIF test

\begin{tabular}{ccc}
\hline Variable & \multicolumn{2}{c}{ Statistics of Collinearity } \\
\hline & Tolerance $(>20 \%)$ & VIF $(<5)$ \\
Interpersonal communication & 0.417 & 2.398 \\
Electronic direct mail & 0.357 & 2.799 \\
Perceived rewards & 0.420 & 2.382 \\
\hline
\end{tabular}

\section{Analysis of Data and Findings}

\subsection{Sample Characteristics}

Table 4 demonstrates the characteristics of the research sample. However, in order to continue in answering the research questionnaire by respondents, two filtering questions were applied to assure if each respondent have had e-transaction with his/her bank, and if he/she have an active account on one or more of these SNSs (Facebook, Twitter and Instagram).

Table 4. Sample characteristics

\begin{tabular}{|c|c|c|}
\hline Variable & Frequency & Percent \\
\hline \multicolumn{3}{|l|}{ The SNS that you use regularly } \\
\hline Facebook & 208 & 41.0 \\
\hline Twitter & 173 & 34.1 \\
\hline Instagram & 126 & 24.9 \\
\hline \multicolumn{3}{|l|}{ Visiting this SNS roughly a day } \\
\hline 1 & 87 & 17.2 \\
\hline 2 & 66 & 13.0 \\
\hline 3 & 144 & 28.4 \\
\hline More than 3 & 210 & 41.4 \\
\hline \multicolumn{3}{|c|}{ Activities respondents do most on this SNS } \\
\hline Chatting & 156 & 30.8 \\
\hline Posting comments & 187 & 36.9 \\
\hline Making new friends & 46 & 9.1 \\
\hline Searching products/services & 118 & 23.2 \\
\hline \multicolumn{3}{|c|}{ Number of banks' customers between contacts on this SNS } \\
\hline Less than 5 & 28 & 5.5 \\
\hline $6-10$ & 94 & 18.6 \\
\hline $11-15$ & 151 & 29.8 \\
\hline More than 15 & 234 & 46.1 \\
\hline Total & 507 & 100.0 \\
\hline
\end{tabular}


According to the descriptive analysis, Table 4 shows the research sample characteristics using frequencies and percentages. The results show that $41 \%$ of banks customers are using the Facebook most regularly; this finding reflects the fact that the Facebook is still dominates the highest share between Jordanian users of SNSs. According to the statistics provided by (checkFacebook.com); Facebook penetration in Jordan reached $41.4 \%$ in (2013), which is in line with the global figures. Furthermore, $41.4 \%$ of the sample is visiting their favorable SNS more than three times a day, so they will probably vulnerable to get massive information, such as customer's reviews or comments about their banks. Instead of the most activity generally customers carry out on their SNS was posting comments with $36.9 \%$; which indicates how customers are willing to exchange different types of information with their contacts, and to show some of self-worth, which totally indicate their personalities, attitudes, lifestyle and so on, which forms more clearer picture for banks marketer to build up tailored messages for their segments. Finally, $46.1 \%$ of customers know more than fifteen contacts as banks customers; this finding reflects the vast volume of opinions/comments expected to be received by banks customers from their contacts on SNSs about the negative or positive experience through banks online practices, which might probably impact customers choices and evaluation of their current or future banks.

\subsection{Sample Demographics}

Table 5 exhibits the research sample demographics. As shown in the table below, the majority of the research' sample were males with $66.1 \%$; the highest age ranged between $31-40$ with $50.3 \%$; for monthly income the category of 700-999 were the highest between respondents, and finally the MBA holders formed the highest educational level within the research sample with $40.0 \%$.

Table 5. Sample demographics

\begin{tabular}{ccc}
\hline Variable & Frequency & Percent \\
\hline Gender & 335 & 66.1 \\
Male & 172 & 33.9 \\
Female & & \\
Age & 38 & 7.5 \\
Less than 20 & 158 & 31.2 \\
$20-30$ & 255 & 50.3 \\
$31-40$ & 56 & 11.0 \\
More than 51 & & \\
Monthly Income & 26 & 5.1 \\
Less than 400 JD & 104 & 20.5 \\
$400-699$ & 211 & 41.6 \\
$700-999$ & 166 & 32.7 \\
More than 1000 & & \\
Educational Level & 57 & 11.2 \\
College community degree & 157 & 31.0 \\
Bachelor's degree & 228 & 45.0 \\
Master's degree & 65 & 12.8 \\
Doctoral degree & $\mathbf{5 0 7}$ & $\mathbf{1 0 0 . 0}$ \\
Total & & \\
\hline
\end{tabular}

\subsection{Hypothesis Testing}

In order to inspect the research hypothesis statistically; multiple regression test has been used to study the effect of interpersonal communication, electronic direct mail and perceived rewards on the eWOM on banks' SNSs. Moreover, examining the mediating role of customer satisfaction between the research' independent and dependent variables

H1: There is an effect of interpersonal communication on eWOM on banks' SNSs.

Table 6 demonstrates the multiple regression analysis results of interpersonal communication on the eWOM on banks' SNSs; the findings indicated that there is a significant and positive effect of interpersonal communication 
on eWOM on banks' SNSs. As shown in the table $12.6 \%$ of the variation in eWOM on banks' SNSs can be interpreted by the interpersonal communication variable, and beta is 0.355 , significant at $(0.000)$. Hence, these findings offer support to accept H1.

Table 6. Regression test for H1

\begin{tabular}{|c|c|c|c|c|c|c|}
\hline $\mathbf{R}$ & R Square & Adjusted R Square & Std. Error of the Estimate & $\mathbf{F}$ & Sig. & H1 Result \\
\hline $.355 \mathrm{a}$ & .126 & .124 & .73740 & 72.94 & $.000^{\mathrm{b}}$ & Accepted \\
\hline \multicolumn{5}{|c|}{ Coefficients } & & \\
\hline \multicolumn{2}{|c|}{ Unstandardized Coefficients } & Standardized Coefficients & fficients & & & \\
\hline $\mathrm{B}$ & Std. Error & Beta & $\mathrm{T}$ & Sig. & & \\
\hline 2.543 & .124 & & 20.518 & .000 & & \\
\hline .286 & .033 & .355 & 8.541 & .000 & & \\
\hline
\end{tabular}

H2: There is an effect of electronic direct mail on eWOM on banks' SNSs.

Table 7 demonstrates the multiple regression analysis results of electronic direct mail on eWOM on banks' SNSs; the findings indicated that there is a significant and positive effect of electronic direct mail on eWOM on banks' SNSs. As shown in the table $17.1 \%$ of the variation in eWOM on banks' SNSs can be interpreted by the electronic direct mail variable, and beta is 0.414 , significant at $(0.000)$. Hence, these findings offer support to accept $\mathrm{H} 2$.

Table 7. Regression test for $\mathrm{H} 2$

\begin{tabular}{|c|c|c|c|c|c|c|}
\hline $\mathbf{R}$ & R Square & Adjusted R Square & Std. Error of the Estimate & $\mathbf{F}$ & Sig. & H2 Result \\
\hline $.414^{\mathrm{a}}$ & .171 & .170 & .71812 & 104.40 & $.000^{\mathrm{b}}$ & Accepted \\
\hline \multicolumn{5}{|c|}{ Coefficients } & & \\
\hline \multicolumn{2}{|c|}{ Unstandardized Coefficients } & Standardized Coefficients & \multirow[b]{2}{*}{$\mathrm{T}$} & \multirow[b]{2}{*}{ Sig. } & & \\
\hline B & Std. Error & Beta & & & & \\
\hline 2.495 & .109 & & 22.821 & .000 & & \\
\hline .317 & .031 & .414 & 10.218 & .000 & & \\
\hline
\end{tabular}

H3: There is an effect of perceived rewards on eWOM on banks' SNSs.

Table 8 demonstrates the multiple regression analysis results of perceived rewards on eWOM on banks' SNSs; the findings indicated that there is a significant and positive effect of perceived rewards on eWOM on banks' SNSs. As shown in the table $15.1 \%$ of the variation in eWOM on banks' SNSs can be interpreted by the perceived rewards variable, and beta is 0.389 , significant at (0.000). Hence, these findings offer support to accept H3.

Table 8. Regression test for H3

\begin{tabular}{|c|c|c|c|c|c|c|}
\hline $\mathbf{R}$ & R Square & Adjusted R Square & Std. Error of the Estimate & $\mathbf{F}$ & Sig. & H3 Result \\
\hline $.389 a$ & .151 & .150 & .72672 & 90.06 & $.000^{\mathrm{b}}$ & Accepted \\
\hline \multicolumn{5}{|c|}{ Coefficients } & & \\
\hline \multicolumn{2}{|c|}{ Unstandardized Coefficients } & Standardized Coefficients & \multirow[b]{2}{*}{$\mathrm{T}$} & \multirow[b]{2}{*}{ Sig. } & & \\
\hline $\mathrm{B}$ & Std. Error & Beta & & & & \\
\hline 2.476 & .119 & & 20.801 & .000 & & \\
\hline .313 & .033 & .389 & 9.490 & .000 & & \\
\hline
\end{tabular}


H4: The effect of eCRM practices (interpersonal communication, electronic direct mail and perceived rewards) on eWOM on banks' SNSs will be mediated by customer satisfaction.

Table 9 demonstrates the multiple regression analysis results of the overall research independent variables, which they are; interpersonal communication, electronic direct mail and perceived rewards on eWOM on banks' SNSs through customer satisfaction as a mediating variable. The findings indicated that there is a significant and positive effect of interpersonal communication, electronic direct mail and perceived rewards on eWOM on banks' SNSs. Consequently, findings offer support to accept H4. Table 9 reveals that $20.5 \%$ of the variation in eWOM on banks' SNSs can be interpreted by the independent variables. Moreover, based on the weighted least square regression test (WLS) the findings indicated that electronic direct mail beta $=0.234$ is significant at $(0.000)$, and perceived rewards beta $=0.200$ is significant at $(0.000)$ formed the highest and strongest predictors of variations respectively. In view of that and in comparison with the values of $\mathrm{R}$ square in the prior tables; the effect of the overall independent variables on the dependent variable will be stronger through customer satisfaction.

Table 9. Regression test (WLS) for H4

\begin{tabular}{|c|c|c|c|c|c|c|c|}
\hline \multicolumn{2}{|l|}{$\mathbf{R}$} & $\begin{array}{c}\text { R } \\
\text { Square }\end{array}$ & Adjusted R Square & $\begin{array}{l}\text { Std. Error of the } \\
\text { Estimate }\end{array}$ & $\mathbf{F}$ & Sig. & H4 Result \\
\hline \multicolumn{2}{|c|}{$.453^{\mathrm{a}}$} & .205 & .200 & 1.21740 & 43.28 & $.000^{\mathrm{c}}$ & Accepted \\
\hline \multicolumn{6}{|c|}{ Coefficients } & & \\
\hline \multicolumn{3}{|c|}{ Unstandardized Coefficients } & \multicolumn{2}{|c|}{ Standardized Coefficients } & & & \\
\hline & B & $\begin{array}{l}\text { Std. } \\
\text { Error }\end{array}$ & Beta & $\mathrm{T}$ & Sig. & & \\
\hline (Constant) & 2.201 & .138 & & 15.929 & .000 & & \\
\hline IC & .057 & .048 & .069 & 1.194 & .233 & & \\
\hline EDM & .180 & .049 & .234 & 3.698 & .000 & & \\
\hline PR & .165 & .047 & .200 & 3.508 & .000 & & \\
\hline
\end{tabular}

\section{Results Discussion and Conclusion}

In order to cope up with customers changing needs and wants and to be competitive in the banking industry; banks operating in Jordan required to make all efforts to add value in their eCRM strategy to create satisfied, loyal and advocate customers, a well designed eCRM practices directly and indirectly affect the scale and scope of eWOM on banks' SNSs. The findings of multiple regression analyses indicated that there is a significant and positive effect of the independent variable eCRM practices which includes (interpersonal communication, electronic direct mail and perceived rewards) on eWOM on banks' SNSs. As well as, customer satisfaction has been found as mediator variable between the independent and dependent variables. As a consequence, all research hypotheses $\mathrm{H} 1-\mathrm{H} 4$ have been accepted; offering an empirical support of the positive relationship between the research variables. Furthermore, the research findings were found to be In line with eCRM, customer satisfaction and eWOM literatures. Likewise, findings point out that, depending on significance and the values of beta; electronic direct mail was the most significant and influential (predictor) on eWOM on banks' SNSs, this result was in line with previous studies (Day \& Hubbard, 2003; Lam, 2013) which supposed that customer detailed profile will lead organizations to customize its products and services and to personalize more the relationships with their customers; and respectively, perceived rewards (O'Brien and Jones, 1995; Lam, 2013) and interpersonal communication (Shu-Chuan \& Yoojung, 2011; Lam, 2013). Furthermore, findings indicated that customer satisfaction positively and strongly mediate the relationship between the independent and dependent variables. In view of that, banks can enhance the overall eCRM strategy from customer perspective, through determine customer's needs, preferences, income etc., which create an obvious picture for banks' marketers to plan and implement powerful activities carried out via these banks' online channels. In addition, since the banking services contains an interactive relationship with banks personnel or means; banks can create wide base of advocate customers on long-term basis through rewarding them fairly and frequently, which make strong barriers for customers to switch off to other competitors. Although banks have to always looking for new customers; the crucial purpose of the eCRM system is to retain current customers satisfied, and if banks were capable to do so; then satisfied customers will turn into a running promotional campaign, through the positive 
experience which almost will be appears as posts or comments on banks' SNSs.

\section{Recommendations and Future Research}

As long as banks have operating eCRM systems and already Jordanian customers are using SNSs, banks' marketers need to explore the most suitable eCRM practices and the main platforms that its customers interact through. The severe competition in the Jordanian banking industry opened unlimited options before customers to pick up the most efficient banks; since banks almost offer the same services with somehow similar charges and interest rate; continua's communication with customers, provide high quality services through both online and offline channels, stick up with customers needs and managing the relationship with them precisely will definitely maintain them in the future. Moreover, Marketers in banks have to pay more attention for their SNSs, especially Facebook and Twitter, and consider them as not only free promotional tools, but also an effective on-to-one marketing communication provided by customers, which create an opportunity for these banks to send more trusted messages through real satisfied and loyal customers.

Eventually, researches in the future within this field possibly will take another service sector such as health care, insurance and telecommunication etc., or to expand the research model to examine more variables related to eCRM or eWOM, or to examine the determinants of applying eCRM; and the role of SNSs in the overall online strategy from banks perspective.

\section{Acknowledgement}

The author is grateful to the applied science private university, Amman, Jordan, for the full financial support granted to this research project (DRGS-2014-2015-39).

\section{References}

Amblee, N., \& Bui, T. H. (2011). The influence of social proof in online shopping: The effect of elec-tronic word-of-mouth on sales of digital microproducts. International Journal of Electronic Commerce, 16(2), 91-114. http://dx.doi.org/10.2753/JEC1086-4415160205

Bataineh, Q. A. (2015). The Impact of Perceived e-WOM on purchase intention: The mediating role of corporate image. International Journal of Marketing Studies, 7(1), 126. http://dx.doi.org/10.5539/ijms.v7n1p126

Burton, J., \& Khammash, M. (2010). Why do people read reviews posted on consumer-opinion portals? Journal of Marketing Management, 26(3/4), 230-255. http://dx.doi.org/10.1080/02672570903566268

Churchill, G. (2001). Basic marketing research (4th ed.). New York: The Dryden Press.

Davis-Sramek, B., Droge, C., Mentzer, J. T., \& Myers, M. B. (2009). Creating commitment and loyalty behavior among retailers: What are the roles of service quality and satisfaction? Journal of Academy of Marketing Science, 37(4), 440-454. http://dx.doi.org/10.1007/s11747-009-0148-y

Day, S. G., \& Hubbard, J. K. (2003). Customer relationships go digital. Business Strategy Review, 14(1), 17-26. http://dx.doi.org/10.1111/1467-8616.00240

Diffley, S., Kearns, J., Bennett, W., \& Kawalek, P. (2011). Consumer behaviour in social networking sites: Implications for marketers. Irish Journal of Management, 30(2), 47-65.

Donaldson, B., \& O’Toole, T. (2007). Strategic market relationships (2nd ed.). Published by John Wiley \& Sons, Ltd.

Fecikova, I. (2004). An index method of customer satisfaction. TQM Magazine, 16(1), 57-66. http://dx.doi.org/10.1108/09544780410511498

Feinberg, R. A., Kadam, R., Kokama, L., \& Kim, I. (2002). The state of electronic customer relationship management in retailing. International Journal of Retail \& Distribution Management, 30(10), 470-481. http://dx.doi.org/10.1108/09590550210445344

Gil-Or, O. (July 2010). Building consumer demand by using viral marketing tactics within an online social network. Advances in Management, 3(7), 7-14.

Goldsmith, R. E., \& Horowitz, D. (2006). Measuring motivations for online opinion seeking. Journal of Interactive Advertising, 6(2), 1-16. http://dx.doi.org/10.1080/15252019.2006.10722114

Hair, J. F. Jr., Black, W. C., Babin, B. J., \& Anderson, R. E. (2010). Multivariate data analysis (7th ed.). Prentice Hall, Upper Saddle River, N.J.

Henke, L. L. (2011). Viral marketing and music videos: When shock tactics backfire. Journal of Behavioral Studies in Business, 4, 1-8. 
Hennig-Thurau, F., Gwinner, K. P., Walsh, G., \& Gremler, D. D. (2004). Electronic word-of-mouth via customer-opinion platforms: What motivates customers to articulate themselves on the internet? Journal of Interactive Marketing, 18(1), 38-52. http://dx.doi.org/10.1002/dir.10073

Hoehle, H., Huff, S., \& Goode, S. (2012). The role of continuous trust in information systems continuance. Journal of Computer Information Systems, 52(4), 1-9.

Jellasi, T., \& Enders, A. (2004). Strategies for e-business (pp. 83-88). Pearson Education Ltd, England.

Jobs, C., \& Gilfoil, D. M. (2012). Less is more for online Marcom in emerging markets: Linking Hofstede's cultural dimensions and higher relative preferences for Microblogging in developing nations. Academy of Marketing Studies Journal, 16(2), 79-96.

Krishnan, M. S., \& Ramaswamy, V. (1999). Customer satisfaction for financial services: The role of products, services and information technology. Management Science, 45(9), 1194-1290. http://dx.doi.org/10.1287/mnsc.45.9.1194

Lam, C. Y., Cheung, R., \& Lau, M. (2013). The influence of internet-based customer relationship management on customer loyalty. Contemporary Management Research, 9(4), 419-440. http://dx.doi.org/10.7903/cmr.11095

Lee-Kelley, L., Gilbert, D., \& Mannicom, R. (2003). How e-CRM can enhance customer loyalty. Marketing Intelligence and Planning, 21(4), 239-248. http://dx.doi.org/10.1108/02634500310480121

Liu, Y. (2007). The long-term impact of loyalty programs on consumer purchase behavior and loyalty. Journal of Marketing, 71, 19-35. http://dx.doi.org/10.1509/jmkg.71.4.19

O'Reilly, K., \& Paper, D. (2009). The role of vendor in e-CRM tool development. Qualitative Market Research: An International Journal, 12(4), 404-427. http://dx.doi.org/10.1108/13522750910993329

Percy, L. (2008). Strategic integrated marketing communication: Theory and practice. New York: Butterworth-Heinemann.

Petrescu, M., \& Korgaonkar, P. (2011). Viral advertising: Definitional review and synthesis. Journal of Internet Commerce, 10(3), 208-226. http://dx.doi.org/10.1080/15332861.2011.596007

Phelps, R. G. (2001). Customer Relationship management. London: Thorogood publishing Ltd.

Reichheld, F. F., \& Sasser, W. E. (1990). Zero defections: Quality comes to service. Harvard Business Review, 68(5), 105.

Ross, D. F. (2005). E-CRM from a supply chain management perspective. Journal of Information Systems Management, 22(1), 37-44. http://dx.doi.org/10.1201/1078/44912.22.1.20051201/85737.5

San José-Cabezudo, R., \& Camarero-Izquierdo, C. (2012). Determinants of opening forwarding e-mail messages. Journal of Advertising, 41(2), 97-112. http://dx.doi.org/10.2753/JOA0091-3367410207

Sekaran, U., \& Bougie, R. (2013). Research methods for business (6th ed.). John Wiley \& Sons, Inc.

Sheth, J. N., \& Atul, P. (1995). Relationship marketing in consumer markets: Antecedents and consequences. Journal of the Academy of Marketing Science, (Fall), 255-271. http://dx.doi.org/10.1177/009207039502300405

Shu-Chuan, C., \& Yoojung, K. (2011). Determinants of consumer engagement in electronic word-of-mouth (eWOM) in social networking sites. International Journal of Advertising, 30(1), 47-75. http://dx.doi.org/10.2501/IJA-30-1-047-075

Svensson, G., Andersson, S., Mysen, T., \& Awuah, G. B. (2009). A comparison of perceived quality in business relationships in Norway and Sweden: Similarities and differences. Baltic Journal of Management, 4(1), 7-33. http://dx.doi.org/10.1108/17465260910930421

Thorbjornsen, H., Supphellen, M., Nysveen, H., \& Pedersen, P. E. (2002). Building brand relationships online: A comparison of two interactive applications. Journal of Interactive Marketing, 16(3), 17-34. http://dx.doi.org/10.1002/dir.10034

Wang, F., \& Head, M. (2006). How can the Web help build customer relationships? An empirical study on e-tailing. Information \& Management, 44(2), 115-129. http://dx.doi.org/10.1016/j.im.2006.10.008

www.abj.org.jo

www.checkFacebook.com 
www.jci.org.jo

www.pewglobal.org

Yeh, Y. H., \& Choi, S. M. (2011). MINI-lovers, maxi-mouths: An investigation of antecedents to eWOM intention among brand community members. Journal of Marketing Communications, 17(3), 145-162. http://dx.doi.org/10.1080/13527260903351119

Yoon, D., Choi, S. M., \& Sohn, D. (2008). Building customer relationships in an electronic age: The role of interactivity of e-commerce web sites. Psychology and Marketing, 25(7), 602-618. http://dx.doi.org/10.1002/mar.20227

Zineldin, M. (2000). Beyond relationship marketing: Technologicalship marketing. Journal of Marketing Intelligence \& Planning, 18(1), 9-23. http://dx.doi.org/10.1108/02634500010308549

\section{Appendix A}

\section{Research Questionnaire}

Part (1) - Sample characteristics:

The following section is about asking banks' customers of their use of social networking sites. For the first two

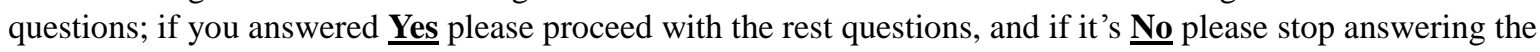
questions.

\section{* Have you ever had an e-transaction with you bank?}

Yes ( )

No ( )

* Do you have an active account on one or more of these social networking sites (Facebook, Twitter, and Instagram)?

Yes ( )

No ( )

1. What is the most social networking site that you use regularly?

Facebook

Twitter

Instagram

$$
\begin{aligned}
& (\quad) \\
& (\quad) \\
& (\quad)
\end{aligned}
$$

2. How frequently do you visit this social networking site on an average day?

$\begin{array}{ll}1 & (\quad) \\ 2 & (\quad) \\ \text { More than } 3 \text { times } & (\quad)\end{array}$

3. What is the most activity do you usually do on this social networking site?

Chatting

Posting comments

Making new friends

Searching products/services

4. Roughly, how many banks' customers do you know between your contacts on this social networking site?

Less than 10

10-19

$20-50$

More than 50 


\section{Part (2) - Sample Demographics:}

\section{Gender:}

Male

Female

2. Age:

Less than 20 years

$20-29$

$30-39$

More than 40

\section{Monthly Income:}

Less than $400 \mathrm{JD}$

$400-699$

$700-999$

More than 1000

\section{Educational Level:}

College community degree

Bachelors degree

Master degree

Doctoral degree

\section{Part (3) - Research Variables:}

The following questions is related to ask banks' customers about the overall research variables; eCRM practices which consist of (interpersonal communication, electronic direct mail and perceived rewards), customer satisfaction and eWOM on banks' SNSs, by using Likert five-point scale, ranging from strongly disagree to strongly agree.

\begin{tabular}{lcc}
\hline Statements & $\begin{array}{c}\text { Strongly Agree Neutral Disagree } \\
\text { Agree }\end{array}$ & $\begin{array}{l}\text { Strongly } \\
\text { Disagree }\end{array}$ \\
\hline
\end{tabular}

\section{Interpersonal Communication}

1. My bank provides detailed online troubleshooting services like (FAQ, Text box dialogue etc.).

2. My bank provides online platforms for customers' to freely express their opinions.

3. My bank provides a lot of online activities like (sweepstakes/games, etc.).

\section{Electronic Direct Mail}

4. My bank always sends me e-mail advertising or electronic newspapers.

5. E-mail advertising or electronic newspapers provided from my bank includes latest services information.

6. My bank always informs me with latest services information which absolutely fall in my interest.

\section{Perceived Rewards}

7. My bank often provides cash or bonus rewards through online channel.

8. My bank always grant me fair permission period for my payments with no extra charges.

9. My bank always sends me gifts or lucky draw promotions through online channel. 


\section{Customer Satisfaction}

10. I am satisfied with interpersonal communication provided by my banks through its online channel.

11. I am satisfied with electronic direct mail provided by my banks through its online channel.

12. I am satisfied with perceived rewards provided by my banks through its online channel.

13. Overall, I am very satisfied with all services provided by my banks through its online channel.

\section{eWOM On Banks SNSs}

14. I tend to pass information about my bank online service to my contacts list on banks social networking sites when I find it useful.

15. When I receive information about banks online services from a friend, I will pass it to my contacts on banks social networking sites.

16. I tend to pass my contacts' with reviews, comments of my bank online services on banks social networking sites.

\section{Copyrights}

Copyright for this article is retained by the author(s), with first publication rights granted to the journal.

This is an open-access article distributed under the terms and conditions of the Creative Commons Attribution license (http://creativecommons.org/licenses/by/3.0/). 